Bulletin d'Histoire Contemporaine de l'Espagne

$50 \mid 2016$

Les intellectuels en Espagne, de la dictature à la démocratie (1939-1986)

\title{
La guerra de Ifni-Sáhara y la lucha por el poder en Marruecos
}

Juan Pastrana Piñero

\section{OpenEdition}

\section{Journals}

Edición electrónica

URL: http://journals.openedition.org/bhce/911

DOI: 10.4000/bhce. 911

ISSN: 1968-3723

\section{Editor}

Presses Universitaires de Provence

\section{Edición impresa}

Fecha de publicación: 1 diciembre 2016

Paginación: 275-276

ISSN: 0987-4135

\section{Referencia electrónica}

Juan Pastrana Piñero, «La guerra de Ifni-Sáhara y la lucha por el poder en Marruecos », Bulletin d'Histoire Contemporaine de l'Espagne [En línea], 50 | 2016, Publicado el 09 octubre 2018, consultado el 24 septiembre 2020. URL : http://journals.openedition.org/bhce/911 ; DOI : https://doi.org/10.4000/ bhce. 911 
la antesala inevitable de la contienda. La República española apenas ha cobrado una entidad propia, reflejando lo pertinente de la citada reivindicación del profesor Tuñón de Lara. En cambio, se lleva a cabo una representación de dos Españas republicanas: una, que lleva la etiqueta negativa de inestabilidad y desorden, comunismo/ fascismo y violencia; y otra idealizadora, reformista, laicista, feminista y democrática, frente al rancio conservadurismo de una España clerical y caciquil.

Estas sensibilidades encontradas se muestran mayormente de forma superficial, manida y falta de una compleja representación, que permite la pervivencia de viejos mitos. Los filmes contribuyen, en suma, a la constitución de una memoria fragmentada, contradictoria, negativa e idealizada del periodo, que impide constituir un simbolismo cinematográfico definido y mejor contextualizado en el imaginario social, lo cual lleva a la pervivencia de mitificaciones (sean positivas o negativas) de la Segunda República por medio del cine.

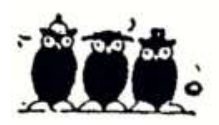

\section{La guerra de Ifni-Sáhara y la lucha por el poder en Marruecos ${ }^{1}$}

\section{Juan PASTRANA PIÑERO}

La tesis propone una revisión de la historiografia existente hasta el momento sobre el último conflicto colonial español. Éste ha sido interpretado, generalmente, como una agresión encubierta del recientemente independizado Reino de

1 Tesis de Historia leída el 5 de abril de 2013, en la Universitat Pompeu Fabra de Barcelona. Director: Dr. Josep Pich i Mitjana. Tribunal: Dr. Eloy Martín Corrales (presidente), Dr. Jesús $\mathrm{M}^{\mathrm{a}}$ Martínez Millán (secretario), Dr. José Antonio Rodriguez Esteban (vocal).
Marruecos contra los últimos vestigios del pasado colonial español. Sin embargo, gran parte de la bibliografía existente proviene de antiguos militares cuya percepción de los hechos viene influenciada por sus vivencias personales.

Por el contrario, la tesis defendida por el Dr. Juan Pastrana Piñero, alejado de dichos condicionantes, aporta nuevas interpretaciones de los hechos sucedidos en la extinta África Occidental Española (A.O.E.) mediante la incorporación de nuevas fuentes de archivo y bibliográficas. Entre las diversas fuentes utilizadas, se encuentran los archivos españoles del Servicio HistóricoMilitar, la Fundación Francisco Franco, el Archivo General de la Administración, el francés del Service Historique de la Défense y los norteamericanos del Department of State y la Central Intelligence Agency. La tesis circunscribe los hechos militares al contexto político del momento, presentando el choque armado como una continuación de los hechos acaecidos en el África Occidental Francesa (A.O.F.) durante 1956 y 1957.

La tesis se encuentra estructurada en cuatro bloques. En el primero de ellos se analizan los orígenes de la presencia europea en el Magreb y el nacimiento del A.O.E., así como su evolución hasta 1956. En este bloque se contraponen los puntos de vista español, francés y marroquí mediante un amplio uso de fuentes bibliográficas procedentes de los tres países implicados en el posterior conflicto, destacando la influencia de hechos como la Conferencia de Algeciras y el choque de intereses coloniales entre España y Francia, así como los acuerdos a que llegaron ambos países europeos para la repartición del Imperio Jerifiano.

El segundo bloque presenta la evolución política marroquí y del A.O.E. durante el período previo al desencadenamiento de las hostilidades, así como la influencia de la política de EE.UU. en la zona. Destaca en este apartado, que reinterpreta la cadena 
de acontecimientos que llevaron a la guerra, el análisis de la lucha por el poder en el interior de Marruecos entre el reinstaurado monarca Mohammed V y el Istiqlal de Allal el-Fassi. Asimismo se analizan las contradicciones de la política española respecto a los primeros movimientos armados del denominado Ejército de Liberación Nacional y la ambigüedad de las autoridades españolas ante la invasión de la Mauritania francesa entre octubre de 1956 y febrero de 1957.

El análisis propiamente dicho del enfrentamiento militar se encuentra en el tercer bloque. En él, además de un análisis crítico de las operaciones militares, se analiza el camino hacia la colusión hispano-francesa que desembocó en la gran ofensiva conjunta en el Sáhara. Las fuentes bibliográficas y de archivo se encuentran completadas por los testimonios de excombatientes españoles, recogidos por el autor mediante una serie de entrevistas efectuadas durante los años de elaboración de la tesis doctoral. Asimismo, en este bloque se analizan episodios accesorios a los hechos acaecidos en el A.O.E., tales como la influencia de la guerra argelina, la postura norteamericana y la acción naval de Agadir.

El cuarto y último bloque se centra en las consecuencias del tratado de Cintra que puso punto y final a los combates. Asimismo, se analiza el posterior desarrollo del territorio de Ifni y la evolución política internacional que llevó a su retrocesión al Reino de Marruecos en 1969. Otro tema analizado es el del posicionamiento y las consecuencias del conflicto sobre la población civil y las tropas nativas al servicio de España, largamente ignorado en la bibliografia existente hasta el momento; complementariamente, el autor realizó una nueva estimación de pérdidas para los tres bandos implicados en el conflicto, basándose tanto en documentación existente como en otra de la que logró la desclasificación en el Service Historique de la Défense.

Se trata, en definitiva, de una tesis que aporta una nueva perspectiva respecto a las publicaciones existentes hasta la fecha, al mismo tiempo que rompe con algunas interpretaciones tradicionales respecto al conflicto de la historiografía española. Desgraciadamente, y a pesar de múltiples e infructuosos intentos, el autor no logró acceder a fuentes documentales marroquíes al habérsele negado el permiso para ello. Este punto quedó cubierto, hasta dónde fue posible hacerlo, mediante el recurso a historiografia de origen magrebí, mayoritariamente publicada en lengua francesa, una de las que domina el autor. Aunque la dificultad de acceso a las fuentes marroquíes ha dejado, por fuerza, algún campo por mejorar, esto no disminuye el interés por el trabajo efectuado. 